Mineralogical Jourval, Vol. 7, No. 2, pp. 169-179, April 1973

\title{
A metastable lithium-beryllium-aluminum silicate with a $\beta$-spodumene structure
}

\author{
HiRoshi Takubo and SHOICHI KUME \\ College of General Education, Osaka University, \\ Toyonaka-shi, Osaka 560 \\ and \\ Mitsue Kolzumi \\ Institute of Scientific and Industrial Research, \\ Osaka University, Suita 565
}

\begin{abstract}
A metastable lithium-beryllium-aluminum silicate " $\mathrm{Li}_{0.34} \mathrm{Be}_{0.88} \mathrm{Al}_{0.66} \mathrm{Si}_{1.98}$ $\mathrm{O}_{6}$ " was prepared by the thermal treatments of a lithium-bearing beryls and of a lithium-free beryls loaded by lithium chloride at temperatures from $620^{\circ} \mathrm{C}$ to $1,170^{\circ} \mathrm{C}$ in air. It is tetragonal with $a=7.502, c=9.120 \AA$, $Z=4$, sp. gr. (obs) $=2.33 \pm 0.11$, sp. gr. (calc) $=2.33, n=1.533 \pm 0.001$, very low birefringence and isotypic with $\beta$-spodumene. Rate of formation of this phase was notably affected by temperature, duration of the heating, lithium concentration and grain size of original beryls. On prolonged heating, it decomposed into the other phase assemblage, suggesting its metastable nature.
\end{abstract}

\section{Introduction}

Experimental results on the phase relationship of beryllium aluminosilicate indicate that the natural beryls of high purity melt incongruently at approximately $1,470^{\circ} \mathrm{C}$, but the alkali-bearing beryls decompose at relatively lower temperatures. Phenacite, chrysoberyl, liquid phase and silica minerals such as quartz or cristobalite are known to be the phases commonly produced by the decomposition. Also, beryl has been known to present similarities to cordierite in respect to crystal structure and high-temperature behavior. Schreyer 
and Schairer (1961) found that a metastable phase appears in the glass of cordierite composition after heating at $900^{\circ} \mathrm{C}$ for a few days. Its $\mathrm{X}$-ray diffraction pattern suggests the structural resemblance to the $\beta$-spodumene studied by Skinner and Evans (1960) or to keatite found by Keat (1954). These evidences lead to a possibility that beryl has such a metastable phase at high-temperature.

In this report, we present some experimental results on the formation of a new phase with the $\beta$-spodumene structure derived from lithium-bearing beryls. For convenience of description, this new phase will be simply abbreviated to " $\beta$-SLB" in this report.

\section{Experiments and results}

The 3 -SLB was formed from natural lithium-bearing beryls and from the lithium-free beryls mixed with either lithium chloride or hydroxide at temperatures ranging from approximately $600^{\circ} \mathrm{C}$ to $1,170^{\circ} \mathrm{C}$. When mixtures of silica, alumina, beryllia and either lithium chloride or lithium hydroxide were used as starting materials, all attempts to produce the $\beta$-SLB failed.

Transformation of natural lithium-bearing beryls

Fragmental samples of two kinds of beryls from South Africa containing 0.32 and $0.98 \mathrm{wt} \%$ of $\mathrm{Li}_{2} \mathrm{O}$, respectively were heated in the different temperatures ranging from $600^{\circ} \mathrm{C}$ to $1,400^{\circ} \mathrm{C}$ in air. The maintenance at high temperature varied from 1 to $1,200 \mathrm{hr}$ in each run. The samples were quenched to room temperature and the products were examined both by a polarizing microscope and by an X-ray diffractometer. On initial heating, the transparency of the samples was lost and either small cracks or partings were found in the plane parallel to (0001) of the original beryl. The microscopic observation disclosed that the formation of a new unknown phase commenced around the rim of fragments of the sample and developed inwards along the fine lamellar partings parallel to (0001) plane. 


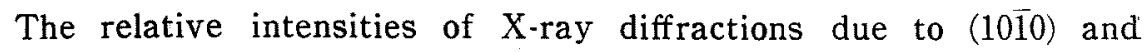
(0002) planes of the original lithium-bearing beryl increased and approached to those of lithium-free beryl. On further heating either at the fixed temperature or at an elevated temperature, the change of the samples into the above-mentioned new phase proceeded, forming the aggregates of fine particles. The $\mathrm{X}$-ray diffraction characteristic for this new phase gradually appeared with the decrease of the diffraction intensities of the original beryls. Finally, the relative heights of the new product attained to saturated values. while those of the beryls remained constant. For example, in case of the lithium-bearing morganite containing $0.98 \mathrm{wt} \%$ of $\mathrm{Li}_{2} \mathrm{O}$, the ratio of height at $d=3.48 \AA$ of the new phase to that at $d_{(21)}=2.87 \AA$ of the beryl reached the maximum value of 0.60 , after heating at $950^{\circ} \mathrm{C}$ for $20 \mathrm{hr}$ at $900^{\circ} \mathrm{C}$ for $160 \mathrm{hr}$ or at $810^{\circ} \mathrm{C}$ for $1,200 \mathrm{hr}$. At temperatures higher than approximately $1,170^{\circ} \mathrm{C}$, the $\beta$-SLB $\operatorname{did}$ not appear, but the direct decomposition of the beryl into phenacite, chrysoberyl and liquid commenced very slowly.

The single phase of $\beta$-SLB was obtained from the mixture of beryls and lithium compounds by appropriate heating manner as described in the later paragraph. The powder diffraction pattern for the single phase of the $\beta$-SLB is given in Figure 1 , together with that for the lithium-bearing morganite which is partly transformed into the $\beta$-SLB after heating at $1,000^{\circ} \mathrm{C}$. For comparison, the pattern for the lithium-free synthetic beryl is also given in the same figure.

\section{Mineralogical properties}

The $\beta$-SLB is obtained in the form of white powder or white fragment composed of fine-grained particles less than a few microns. in size. Specific gravity was measured by the sink-float technique. The powder or the fragment of the $\beta$-SLB was suspended in heavy liquid for $12 \mathrm{hr}$ in order to determine whether it sank or floated. 


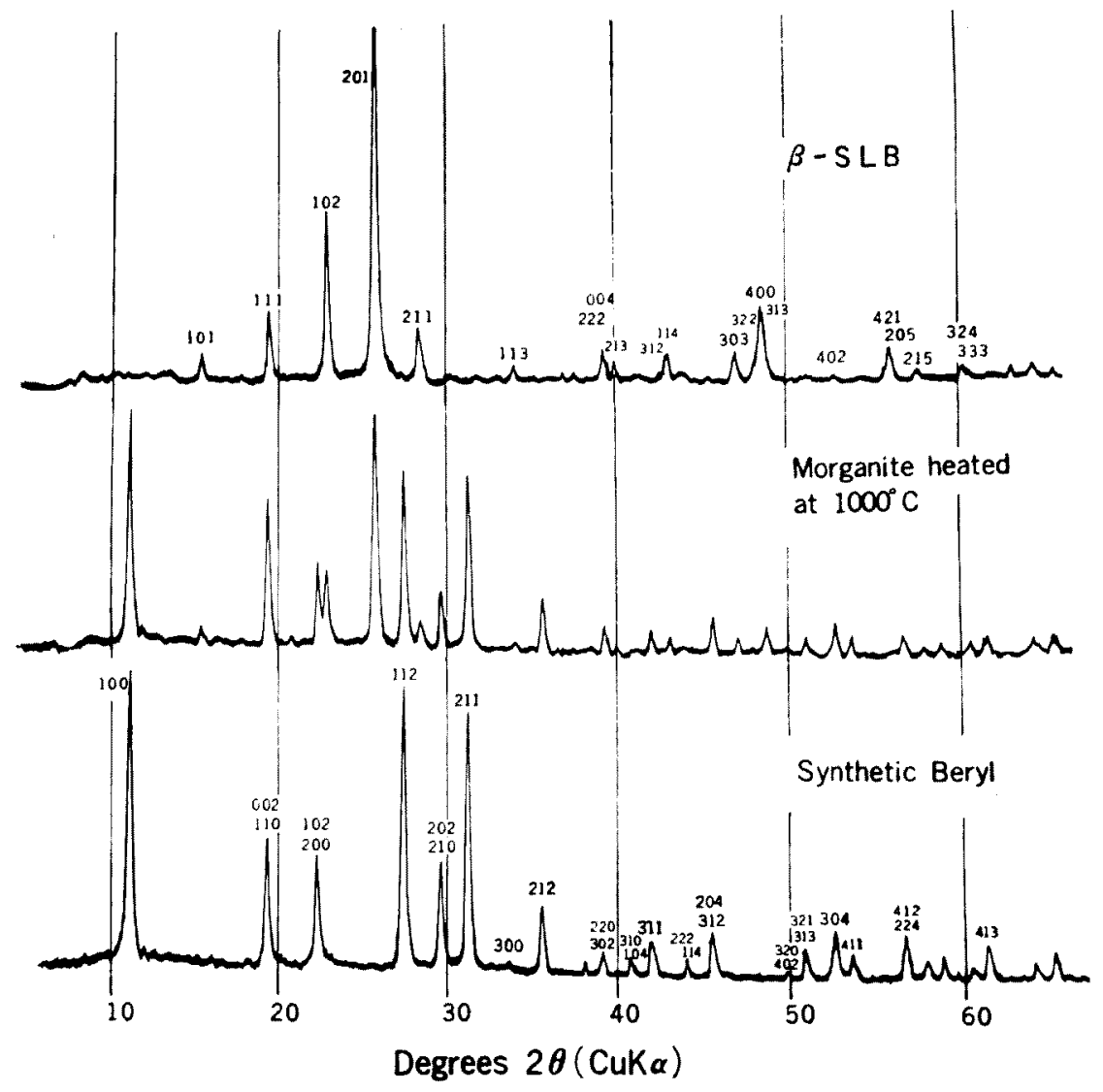

Fig. 1. X-ray powder diffraction patterns of the $\beta$-SLB, obtained by heating the mixture of beryl and lithium chloride at $900^{\circ} \mathrm{C}$ for $96 \mathrm{hr}$ (top), morganite heated at $1,000^{\circ} \mathrm{C}$ for $96 \mathrm{hr}$ (middle) and beryl synthesized from gel of ideal beryl composition $\left(\mathrm{Al}_{2} \mathrm{Be}_{3} \mathrm{Si}_{6} \mathrm{O}_{18}\right)$ at $600^{\circ} \mathrm{C}$ and $\mathrm{P}_{\mathrm{H}_{2} \mathrm{O}} 2 \mathrm{~kb}$ (bottom).

The mean specific gravities determined in this way were $2.33 \pm 0.11$. Because of the fine grain size, the optical sign could not be determined. The mean refractive index determined by the immersion method for sodium light was $1.533 \pm 0.001$. Very weak birefringence, approximately 0.002 , was observed on the particles of comparatively large size. 
Table 1. X-ray powder data for $\beta$-SLB, $\beta$-spodumene and metastable solid solution with quartz-type structure crystallized from glass of cordierite composition. The $d$-spacings were calculated using a tetragonal cell with $a=7.502 \AA$ and $c=9.120 \AA$.

\begin{tabular}{|c|c|c|c|c|c|c|c|c|}
\hline \multicolumn{4}{|c|}{$\beta-S L B$} & \multicolumn{2}{|c|}{$\beta$-spodumene* } & \multicolumn{3}{|c|}{$\begin{array}{l}\text { Metastable quartz** } \\
\text { solid solution }\end{array}$} \\
\hline$h k l$ & $d_{\mathrm{obs}}$ & $I$ & $d_{\text {calc }}$ & $d_{\text {obs }}$ & $I$ & $h k l$ & $d_{\mathrm{obs}}$ & $I / I_{0}$ \\
\hline 101 & 5.800 & 1 & 5.793 & 5.821 & 3 & & & \\
\hline 110 & - & & - & 5.340 & 0.5 & & & \\
\hline 111 & 4.583 & 1 & 4. 585 & 4. 610 & 5 & 100 & 4. 505 & 20 \\
\hline 102 & 3. 897 & 3 & 3.900 & 3.920 & 6 & - & - & \\
\hline 201 & 3.463 & 10 & 3. 469 & 3.487 & 10 & 101 & 3. 446 & 100 \\
\hline 211 & 3.145 & 1 & 3. 149 & 3. 167 & 5 & & & \\
\hline 103 & - & & 2.856 & 2. 858 & 1 & & & \\
\hline 113 & 2.638 & 1 & 2.638 & 2.628 & 3 & 110 & 2. 600 & 6 \\
\hline 222 & 2. 292 & 1 & 2. 293 & 2.304 & 4 & 102 & 2. 296 & 4 \\
\hline 004 & $2.275\}$ & 1 & 2. 280 & 2. 291 & 1 & & & \\
\hline 213 & 2. 252 & 1 & 2. 253 & 2. 264 & 4 & 200 & 2. 252 & 15 \\
\hline 104 & 一 & & - & 2.191 & 2 & & & \\
\hline 312 & 2.103 & 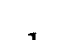 & 2. 105 & 2.113 & 4 & & & \\
\hline 114 & 2. 094$\}$ & 1 & 2.095 & 2.106 & 1 & 201 & 2.075 & 10 \\
\hline 303 & 1.930 & 1 & 1. 930 & 1. 938 & 5 & & & \\
\hline 322 & 1.893 & 1 & 1.893 & 1.899 & 1 & & & \\
\hline 400 & 1.873 & 2 & 1.876 & 1.882 & 6 & 112 & 1.863 & 30 \\
\hline 313 & 1.868 & & 1.870 & 1.873 & 6 & & & \\
\hline 402 & 1.733 & 0.5 & 1.735 & 1. 742 & 1 & 202 & 1.721 & 2 \\
\hline 323 & - & & 1. 717 & 1. 723 & 0.5 & 210 & 1. 703 & 5 \\
\hline 412 & - & & 1. 690 & 1. 697 & 2 & & & \\
\hline 421 & 1. 648 & 1 & 1. 650 & 1.656 & 2 & 103 & 1.655 & 5 \\
\hline 205 & 1.640 & 1 & 1.640 & 1.646 & 4 & 211 & 1.623 & 15 \\
\hline 215 & 1.597 & 0.5 & 1. 602 & 1.608 & 1 & & & \\
\hline 324 & $1.536\}$ & 05 & 1. 537 & 1. 543 & 2 & & & \\
\hline 333 & $1.527\}$ & 0.5 & 1. 533 & 1.535 & 2 & 300 & 1. 502 & 1 \\
\hline 106 & - & & 1. 490 & 1. 494 & 0.5 & 113 & 1. 469 & 1 \\
\hline
\end{tabular}

* Skinner and Evans (1960) ** Schreyer and Schairer (1961) 
$X$-ray powder diffraction data on the $\beta$-SLB are given in Table 1. For comparison, the $d$-spacings of $\beta$-spodumene (Skinner and Evans, 1960) and of the metastable quartz solid solution of cordierite composition (Schreyer and Schairer, 1961) are also given in the same table. Since the $d$-values of the new phase were almost equal to those of $\beta$-spodumene, the diffraction data could be indexed on the basis of tetragonal unit cell with $a=7.502 \AA$ and $c=9.120 \AA$ as shown in the left column of Table 1 . For comparison, those for $\beta$-spodumene obtained by Skinner and Evans (1960) are $a=7.533 \AA$ and $c=$ $9.154 \AA$ respectively. Schreyer and Schairer (1961) synthesized the metastable quartz solid solution of cordierite composition and this phase resembles the $\beta$-SLB in the diffraction pattern as shown in Table 1. They gave a hexagonal unit cell with $a=5.200, c=5.345 \AA$ to this phase. However, crystallographic data measured for the $\beta$-SLB show better agreement with those calculated on the basis of tetragonal unit cell.

The chemical composition of the single phase of the $\beta$-SLB is shown in Table 2. The chemical formula obtained from this table on the basis of six oxygen atoms is $\mathrm{Li}_{0.34} \mathrm{Be}_{0.88} \mathrm{Al}_{0.66} \mathrm{Si}_{1.98} \mathrm{O}_{6}$. If four units of this formula are contained in the unit cell of the $\beta$-SLB, the specific gravity is calculated to be 2.33 and this is in good agreement with the measured mean value of $2.33 \pm 0.11$.

Table 2. Chemical composition of the $\beta$-SLB.

\begin{tabular}{cccccc}
\hline $\mathrm{SiO}_{2}$ & $\mathrm{Al}_{2} \mathrm{O}_{3}$ & $\mathrm{BeO}$ & $\mathrm{Li}_{2} \mathrm{O}$ & Ign. Loss & Total (\%) \\
65.97 & 18.68 & 12.27 & 2.81 & 0.06 & 99.79 \\
\hline
\end{tabular}

Syntheses from the mixture of lithium-free beryls and lithium compounds

Neither lithium-free beryls nor synthetic beryl crystals with ideal composition changed into the $\beta$-SLB at any condition investigated. However, an addition of appropriate amount of lithium 
chloride or hydroxide caused a change almost similar to those in the case of lithium-bearing beryls. Two kinds of lithium-free beryl were used as the starting materials. The one is the colorless beryl from Ishikawayama, Fukushima Prefecture, Japan, and the other is the synthetic beryl made from the gel with ideal chemical composition under the hydrothermal condition of $600^{\circ} \mathrm{C}$ and $1,500 \mathrm{~atm}$ for 2 weeks.

The grain size of the natural beryl was controlled so as to be about 0.5 to $1 \mathrm{~mm}$ for fragmental sample and 0.061 to $0.074 \mathrm{~mm}$ for the powder. The grain size of the synthetic beryl ranged from 0.01 to $0.02 \mathrm{~mm}$. 2 to $5 \mathrm{~g}$ of these samples were mixed with desirable amounts of lithium chloride solution containing $0.05 \mathrm{~g}$ of lithium ion per $100 \mathrm{ml}$. The mixture was put into a platinum crucible and condensed and dried at $80^{\circ} \mathrm{C}$. Mechanical agitation was carried on during these processes in order to prevent the differentiation of the mixture. The calcination of the mixture was made at $450^{\circ} \mathrm{C}$ for 24 $\mathrm{hr}$ and further $620^{\circ} \mathrm{C}$ for $24 \mathrm{hr}$ in order to prevent the abrupt evaporation of lithium chloride at the higher temperature. After heating at the same conditions as those in the case of lithiumcontaining beryls, the sample was quenched, carefully washed by water to expell the residual lithium chloride and dried at $110^{\circ} \mathrm{C}$. As the source of lithium component, lithium chloride was mainly used, because lithium hydroxide was caustic to platinum crucible at high temperature, although the use of this material gave the same result as in the case of lithium chloride.

It was confirmed that, at temperatures higher than $1,170^{\circ} \mathrm{C}$, the $\beta$-SLB did not appear but the direct decomposition of the beryl into the assemblage of phenacite, chrysoberyl and liquid took place. It was also confirmed that the $\beta$-SLB did not revert into the state of original samples on reheating at temperature-range between $400^{\circ} \mathrm{C}$ and $1,400^{\circ} \mathrm{C}$ at $1 \mathrm{~atm}$ and at $600^{\circ} \mathrm{C}$ and $1,500 \mathrm{~atm}$ of water pressure. 
Rate of formation

The amount of $\beta$-SLB produced from lithium-bearing beryls and the mixtures of beryl and lithium chloride at high temperatures was found to be dependent on temperatures, the durations of runs, the concentration of lithium chloride and the grain size of the original beryl. The rate of formation was determined by the measurements of relative heights of $\mathrm{X}$-ray diffraction peaks of the beryl and $\beta$-SLB in coexistence.

Figure 2 shows the relation between the temperature of treatment and the height corresponding to $d=3.463 \AA$ of the $\beta$-SLB phases which were formed from morganite (curve $\mathrm{AA}^{\prime}$ ) and the lithiumbearing natural beryl (curve $\mathrm{BB}^{\prime}$ ). It is seen that the formation of the $\beta$-SLB commences at $850^{\circ} \mathrm{C}$ for morganite and $870^{\circ} \mathrm{C}$ for the lithium-bearing beryl and that temperatures favorable to produce the $\beta$-SLB are limitted and beyond this range the amount of the production decreases.

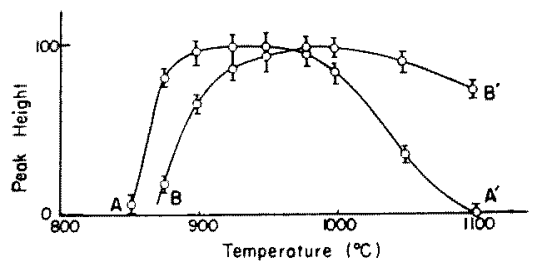

Fig. 2. Relationship between the temperature of treatment and the amount of $\beta$-SLB made from morganite (curve $\mathrm{AA}^{\prime}$ ) and the lithium-bearing natural beryl (curve $\left.\mathrm{BB}^{\prime}\right)$. The duration of treatment was one week. The amount of production was estimated by the height of diffraction pattern at $d=3.463 \AA$.

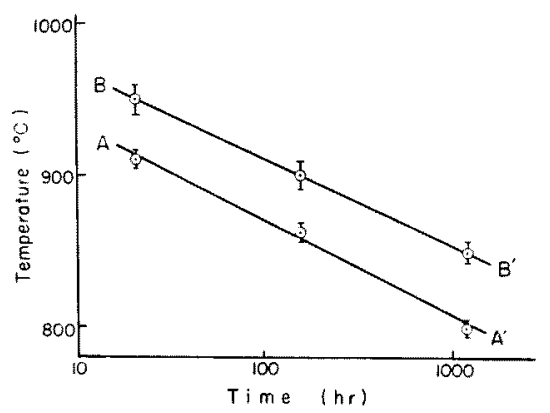

Fig. 3. Decomposition of morganite containing $0.98 \mathrm{wt} \%$ of $\mathrm{Li}_{2} \mathrm{O}$ as a function of temperature and time of heat-treatment. The curve $\mathrm{AA}^{\prime}$ shows the lower limit of the range where the $\beta$-SLB is formed. The curve $\mathrm{BB}^{\prime}$ shows the lower limit of the range where the formation of $\beta$-SLB is completed. 
The duration of heating strongly affected the temperatures at which the $\beta$-SLB first appeared and attained the maximum rate of formation. Figure 3 shows the relationship between the temperature and the duration of heating to obtain a certain amount of the $\beta$-SLB in case of morganite. The curve $\mathrm{AA}^{\prime}$ in the figure was obtained by plotting the temperatures at which the $\beta$-SLB was first detected by X-ray diffraction on heating for 21,156 and $1,200 \mathrm{hr}$. The curve $\mathrm{BB}^{\prime}$ was drawn similarly using the temperatures at which the amount of the $\beta$-SLB atrains the maximum values on heating for the same duration as those stated above. As seen in the figure, the temperature of formation of the $\beta$-SLB is lowered by the increase of the duration of heating. In the runs using the mixture of synthetic lithium-free beryl and lithium chloride, the similar tendency was recognized.

The amount of lithium ion contained either in the natural beryls or in the mixture of lithium-free beryl and lithium chloride was found to affect the condition of formation of the $\beta$-SLB.

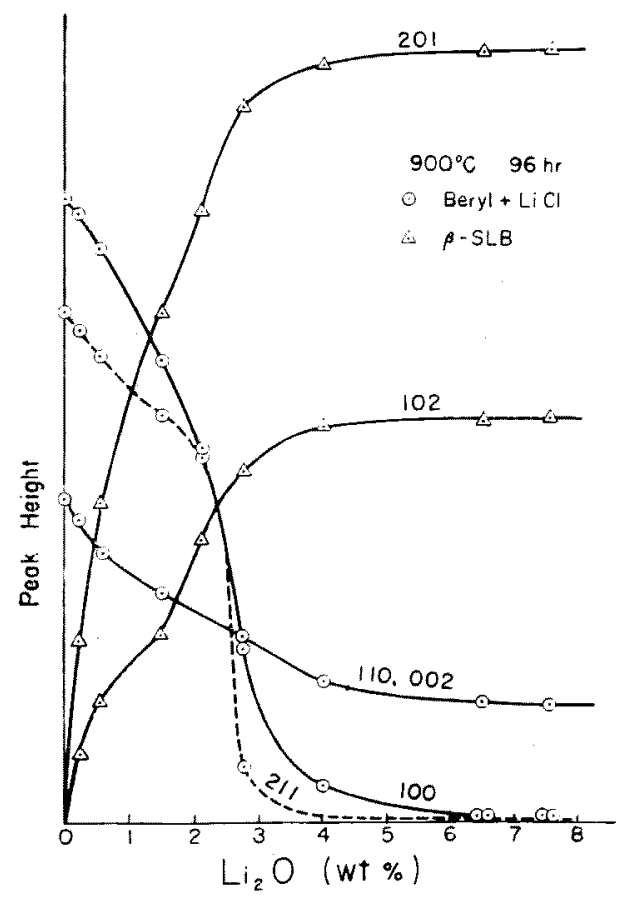

Fig. 4. Relative amounts of the original beryls remained and the $3-S L B$ produced in the mixtures of the lithium-free synthetic beryl and lithium chloride, after the heating at $900^{\circ} \mathrm{C}$ for $96 \mathrm{hr}$; plotted against analysed value of $\mathrm{Li}_{2} \mathrm{O}$-content in the mixtures. The $\mathrm{Li}_{2} \mathrm{O}$-content corresponds to the total amount of lithium ions both in the $\beta$-SLB and the residual lithium chloride. 
With the increase of the amount of lithium chloride in the starting materials, the rate of formation of the $\beta$-SLB at a given temperature increased and the lowest temperature of the formation for a fixed time was reduced. An example is shown in Figure 4. In this figure, it is seen that the decomposition of beryl and the formation of the $\beta$-SLB proceed almost completely in the presence of $\mathrm{Li}_{2} \mathrm{O}$ of approximately 2.5 to $3.5 \%$ of the total weight under the investigated conditions.

\section{Discussion}

By Van Valkenburg and Weir (1957), Miller and Mercer (1965), and Munson (1967), natural beryls have been known to be stable at 1 atm up to approximately $1,470^{\circ} \mathrm{C}$, at which the incongruent melting commences, although alkali-bearing beryls is unstable in temperature range from $900^{\circ}$ to $1,200^{\circ} \mathrm{C}$ as reported by Frank-Kamenetskii and Sosedko (1966). The results of present experiment suggest that the natural lithium-bearing beryls such as morganite are more unstable than the lithium-free beryls at high temperature.

The metastable nature of the $\beta$-SLB was expected from the following facts: (1) Formation of the $\beta$-SLB requires the presence of beryl crystal in the starting materials. (2) The temperatures of the formation vary as the duration of heating changes. (3) The $\beta$-SLB does no revert into lithium-bearing beryl at conditions investigated here. (4) The $\beta$-SLB gradually changes into another assemblage of phenacite, chrysoberyl and liquid or into the mixture of $\beta$-spodumene and bromellite. This decomposition is accelerated either by rising temperature or by prolonged heating.

Deer, Howie and Zussman (1962) have pointed out that spodumene is known as one of the minerals associated with beryl. The present study provides an experimental evidence of this coexistence. showing the possibility of occurrence of the spodumene containing. an appreciable amount of beryllium ion in nature. 


\section{REFERENCES}

DeEr, W.A., Howie, R.A. \& Zussmax, J. (1962) Rock-Forming Minerals, vol. 1. Longmans, Green and Co. LTD, London.

Frank-Kanexetskin, V.A. \& Sosedko, T.A. (1966) Zap. Vses. Miner. Obshchest., 95, 728 Chem. Abstr., 66, 6402, 1967] (in Russian).

KEAT, P.K. (1954) Science, 120, 328.

Miller, R.P. \& Mercer, R.A. (1965) Miner. Mag., 35, 250.

Muson, R.A. (1967) J. Amer. Ceram. Soc., 50, 669.

SCHREYER, W. \& Schairer, J.F. (1961) Zeits Krist., 116, 60.

SkMver, B.J. \& Evass, H.T. (1960) Amer. J. Sci., 258, 312.

VAx Valkenblrg, A. \& Weir, C.E. (1957) Bull. Geol. Soc. Amer., 68, 1808.

Received February 20, 1973 